\title{
8
}

\section{'The Main Thing Is to Have Enough Food': Kuninjku Precarity and Neoliberal Reason}

\author{
Jon Altman
}

Being able to get to your country and being able to live here too, that's the good life. Sometimes going bush, sometimes living here; the main thing is to have enough food. When you have enough food to eat, that's good.

These opening lines are drawn from a series of interviews conducted in Kuninjku, a dialect of the pan-dialectical language Bininj Kunwok (Garde, 2013) during a week in February 2015. 'The focus of my questioning was on what constitutes the 'good life' today, in the immediate past and, potentially, in the future. The question was posed to John, my friend of nearly 40 years, in his language by Murray Garde, expert linguist and accredited translator. I asked the question sitting on the ground outside John's decrepit government-supplied home at the remote township of Maningrida in Australia's Northern Territory.

1 I made this methodological decision because my Kuninjku is too limited to be immune from potential misrepresentation or error and I was keen to have Murray Garde's expert assistance. Interviews were conducted with a cross-section of Kuninjku speakers, mainly old and middle-aged, but including some young people, mainly male, but also females. The interviews were conducted in the township of Maningrida during the wet season when most Kuninjku are living there rather than at their small homelands in the hinterland. 
John's response can be multiply interpreted, but there are two key messages. One is about mobility and maintaining connection to one's country. John continues:

What makes me happy is when I go back to my home out bush and I can go out hunting and I can live like the old people from olden times. That makes me happy when I am in my camp, I can paint, I can drink tea and walk around my camp and the sun goes down. Good, happy. In Maningrida, sometimes happy, sometimes not. I only think about my country. I get sad when I think about my home out bush and I can't get out there. This place here is for white people, but it gives us access to Balanda [Western] food and to health services at the clinic. We can go out bush but the problem is when we get sick or when we have no [Western] food out there. So it pushes us to come and live here to get Balanda food and health services, but we still want to live out bush. It is a contradiction that frustrates us.

The other key message indexed by John's reflections is about what might be referred to in Australian English as 'getting a good feed', or what we might think of as 'food sovereignty' ( $\mathrm{Li}, 2015)$. John talks about food in two ways: Balanda (or Western) food, which is purchased from the store; and bush tucker, which is hunted, fished or gathered:

I am worried about my country and those old people buried there or when they used to go collecting food ... [he lists all kinds of bush food]. I think about those old people and the food we used to eat.

In the middle of this interview, Peter, a white man (or Balanda) who lives in Maningrida and has worked for years with the Maningrida Progress Association, which runs a local store selling Balanda food, arrives with a large fish (a barramundi) he has caught for John.

'Why did he give you that fish?' I ask.

'For supper, because we have no food,' says Kay, John's wife.

'He must have caught it on my country,' says John.

Ngarritj, John's grandson, says, 'Peter goes hunting at Bulkay and he gives them fish.'

Later, I ask the same question of Peter, who tells me that he delivered the fish to John's camp because Kay had asked for it. She had told him they were hungry; it was caught near Maningrida in salt water, not in the fresh water at Bulkay. 
Just prior to Peter's arrival, I had been showing John my book HunterGatherers Today: An Aboriginal Economy in North Australia (Altman, 1987), based on my anthropological fieldwork in 1979 and 1980 at Mumeka outstation on John's country. The book features a photograph of a young John on the front cover holding bush food-a goanna, magpie geese, a barramundi and a catfish-from a hunt he and I undertook at Bulkay. I had asked John:

'If I was to write a book about what people do every day [today] in Maningrida, what would I write?'

He replied: 'I don't know. I am going to try to tell everyone to go back to our outstation.'

'What about bush tucker?'

'Before bush tucker.'

Earlier, Japhat, another Kuninjku man, had commented:

We have a lot of bush tucker out bush. Before, a long time, the old people thought a lot about bush tucker, but the new generation they think about the foods that white people have brought, sugar, bakky [tobacco]. The white people's food has changed our thinking. We don't think about our bush foods as much.

In this chapter, I want to ask why the struggle 'to get a feed' (in colloquial Australian) and remain connected to one's country can be so difficult for someone like John Mawurndjul, who is among Australia's foremost contemporary artists, living in one of the richest countries in the world.

On several occasions recently, and with increasing frequency in the last decade, I have known Kuninjku people to be hungry and without food in Maningrida. Sometimes, prior to sitting down for a meeting or social gathering, they have asked me to buy them food, an unusual request in my nearly four decades of acquaintance. Such requests have been made reluctantly and with a degree of shame; they are in marked contrast to the high visibility and ready availability of food out bush and offers of bush tucker made to me on my visits to outstations. 
There are two issues here I seek to analyse. Living in Maningrida today, mainly on welfare, what people are short of is food sourced from the store. This is because their income is low and this food is expensive. When they live in the hinterland they have access to abundant bush food, although they often lack access to Western foods. However, they increasingly find it difficult to live at their outstations, even though this is the stated preference of many of their senior people, like John, who recognise, with some sadness and frustration, that this is not an aspiration necessarily shared by young people, the so-called new generation.

My introduction so far has focused on Kuninjku perspectives and agency, something that Kuninjku themselves emphasise. However, this is only a small part of a bigger story in a context in which the role of the Australian settler state and its ever-changing policy approaches to Aboriginal development looms large in the structuring and restructuring of people's livelihood options.

I wish to deploy the historical technique of the longue durée to give a degree of priority to historical structures over events. John came in from the bush, where he was being reared as a member of a hunter-gatherer group, to Maningrida in 1963. I first met him 16 years later in 1979. During the following 37 years, 1979-2016, I have visited him in Arnhem Land regularly, and he in turn has visited me in Canberra on several occasions. In that time, the livelihood fortunes of Kuninjku people have fluctuated quite dramatically, always heavily structured by relations with the state. What I aim to do here, then, is to trace a series of social experiments that have been conducted on Aboriginal people residing in remote Australia and examine their effects, as experienced by the subjects of those experiments.

I begin by providing a contextualising background on the Maningrida region. I then give a brief account of two historical periods that preceded my initial engagement in this region, which I term 'precolonial' and 'colonial'. I then focus on two periods, the first underway by the 1970 s, which I term 'postcolonial', and the second, clearly manifest from about 2005 to the present, which I term 'neo-colonial', the latter being my priority. 
Each of these phases has greatly influenced the nature of the Kuninjku livelihood and domestic economy and their transformation in ways that have not necessarily followed the Western development pathways imagined and promised by state officials. While the materialist and structural nature of my analysis dovetails with Wolfe's theorisation $(1999,2015)$ - that the logic of settler society and late capitalism is to have unimpeded access to the land and its resources-for a time, in the postcolonial period, it appeared that Kuninjku might be able to resist the destruction and elimination of their native society. In the contemporary neo-colonial context, this process of elimination, proposed to occur through beneficial integration of Kuninjku into the mainstream, has re-emerged. It is my contention that, for people like the Kuninjku, any form of forced integration constitutes a form of structural (Farmer, 2005) and economic violence (Peck, 2010).

This chapter is written at a moment when the democratically elected Australian Government is unwilling to support the rights of Indigenous Australians to live differently-indeed, in which there is a dogged and bipartisan national policy focus on 'Aboriginal advancement to integration' (Schapper, 1970). In this context, the complex politics of constitutional recognition of Indigenous peoples has stalled; there are policy proposals to defund and close down small Indigenous communities, usually with populations of less than 100 , even where land rights or native title have been legally recognised; ongoing debates about the possible amendment of racial discrimination law to allow racial vilification as a libertarian right to free speech; and ongoing special discriminatory laws that target Indigenous people.

The dominant policy framework, agreed upon by all Australian governments since 2008, is the supposedly humane but ultimately developmental and modernist Closing the Gap strategy, which has clear aims to eliminate statistical disparities between Indigenous and other Australians. The Australian Government's Indigenous Advancement Strategy is quite explicit in its aim to alter the norms and values of Indigenous peoples to match those of mainstream Australians, and to deliver supposedly equalising outcomes to Indigenous people, including the Kuninjku, measured by Western statistics (Council of Australian Governments, 2011). 


\section{The Maningrida Region: Synoptic Background}

The township of Maningrida looms large in the lives of Kuninjku people today and so I want to provide a brief summary of its establishment, its peoples and the region. Maningrida was originally called Manayingkarirra (from the phrase Mane djang karirra, meaning 'the place where the Dreaming changed shape'), a camping place on a river, now called the Liverpool River, on the lands of the Dekurridji clan. In 1949, a trading post was established by what was then the Native Affairs Branch of the Northern Territory Administration as a policy experiment to repatriate 'tribal' people who had walked to Darwin, 500 kilometres away. It was abandoned in 1950 .

In 1957, Maningrida was re-occupied by state officials and established as a Welfare Branch government settlement to create a regional colonial presence deep within what was then the Arnhem Land Aboriginal Reserve, and, again, to help to keep Aboriginal people out of Darwin. Government policy at that time embraced assimilation-the quest to transform Aboriginal people into mainstream subjects. Maningrida slowly developed over the 1960s into a township where Aboriginal people, still wards of the state, could be trained for assimilation through education and work and the adoption of Western ways of living.

Since 1957, Maningrida has had both Balanda (non-Indigenous) and Bininj (Aboriginal) populations. It is a place of dual ethnicity, with power legally vested with Balanda as agents of the colonial state. In the early 1970s, policy shifted dramatically from imposed assimilation, which had failed, to decolonising self-determination, which was initially viewed by all with great optimism as a means to empower Aboriginal people and to overcome earlier development failures. However, this was a constrained self-determination, with state authority still reigning supreme, as symbolised by the coat of arms fixed to the wall of 'Her Majesty's' Maningrida police station and the flags of Australia and the Northern Territory flying outside the West Arnhem Shire office.

The Maningrida region covers about 10,000 square kilometres of tropical savannah. It has a current Aboriginal population of about 3,000 and a nonAboriginal population of about 300 , although the accuracy of available statistics, even from the five-yearly official census, are of dubious veracity. I conceptualise this region geopolitically as comprising two spaces: 
a township or service centre of about 300 houses, shops, a school, a police station and other service facilities; and a hinterland where 100 houses are scattered across about 35 locations called outstations. I try to avoid using the term 'community' when talking about Maningrida because it is made up of diverse residential clusterings (or 'communities') defined by languages, lineages, political alliances, land ownership in the hinterland and territorial orientations. Occupational affiliations mainly define the Balanda groupings - teachers, nurses, those employed in various Aboriginal organisations and so on-and their residential clustering.

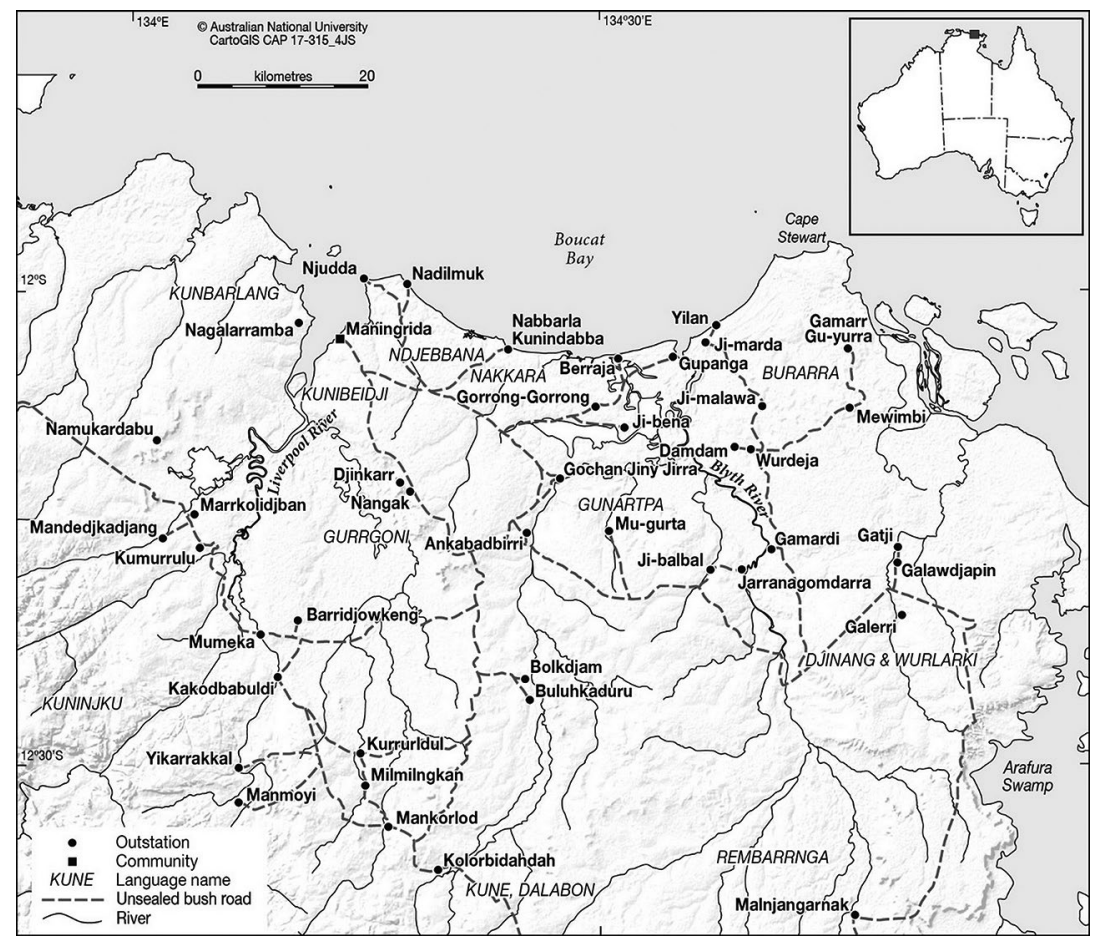

Figure 8.1: Map of the Maningrida Region

Source: CartoGIS, College of Asia and the Pacific, The Australian National University.

Figure 8.1 summarises the location of the region in tropical north Australia; the spatial relationship between Maningrida and far smaller outstations averaging populations rarely over 25 persons; and the main geographic distribution of regional languages (shown capitalised in the map), of which the Kuninjku dialect is just one. Maningrida today is a multilingual township, with speakers of all regional languages resident since its establishment. Associated with language diversity, there is 
also political diversity and contestation; Maningrida is located on the land of the Dekurridji, whose ownership was only legally recognised after the passage of land rights law in 1976. Historically, other more demographically powerful groups with superior cross-cultural skills had been politically dominant at Maningrida. Today, the Dekurridji and their affines and close allies have recouped some local authority, which remains very much subordinate to that of the state. No social field in this region is either typical or static; they vary in size, regional mobility, adherence to customary law and place of residence. The main integrating regional institutions are Aboriginal ritual cult, mortuary and social exchange ceremonies, Christian fellowship (for those who participate) and Australian Rules football.

My focus on the Kuninjku in this chapter mainly reflects my long-term research relationship with this group. I have been working with them since 1979; yet, attempting to define even them as a community or social field is challenging. There are about $300 \mathrm{Kuninjku}$, so defined because they speak a dialect of the pan-dialectical Bininj Kunwok language, whose speakers reside in the Kakadu-West Arnhem region (Evans, 2003; Garde, 2013). The Kuninjku community I work with is located at the eastern extremity of this language bloc and is mainly composed of members of six intermarrying clans defined by patrilineal descent. Kuninjku in general 'marry' each other in accord with customary marriage rules, which emphasise clan and moiety exogamy as a core principle. They also sometimes marry their immediate neighbours, especially members of other Bininj Kunwok dialect groups to the west. They are associated with 10 outstations and use territories they own under land rights law for livelihood and spiritual sustenance.

Key distinguishing features of this 'community' include Kuninjku people's relatively recent contact with the colonial state, remnants of the community only moving to Maningrida in 1963; their eagerness to decentralise in the 1970s-Kuninjku were among the first in north Australia to do so; their poor adaptation to settlement life; and their practice, like other groups but more so, of moving continually between township and hinterland, and between outstations. However, in the last decade or so, a number of Kuninjku families have been settled in Maningrida almost continuously for employment, children's education and access to health services. The future permanence of such residential choice is difficult to assess given historical shifts from outstations to town and vice versa. 
When Kuninjku are in Maningrida they reside in four residential clusters they call 'bottom camp', 'side camp', 'shelter' and 'new sub', the last a recent 'suburban' addition to the township, consisting of 100 houses constructed for Aboriginal residents since 2009. In total, the Kuninjku camps consist of 10 houses in various states of disrepair and four 'temporary' tin sheds (in use for over a decade), which they refer to as 'chicken houses'. These residential clusters are spread across the township but are oriented towards Kuninjku country to the south-west. The defining sociological feature of these clusters is that residents predominantly share hunted game and store-purchased foods, as well as cash, with each other on the basis of kinship ties. There is also an emerging Kuninjku camp at a place called 'the Fifteen Mile' just outside Darwin, where Kuninjku rent two very basic shelters from the Department of Housing and Community Development. The main emerging reason for visiting Darwin is access to kidney dialysis treatment, another being access to alcohol, which is hard to find in Maningrida. The interviews recorded for this chapter were conducted at or near each of these camps.

\section{Hunter-Gatherers Primed for Developmental Assimilation}

Until the late 1950s, and even into the early 1960s, Kuninjku people lived as hunter-gatherers in what was effectively an un-colonised part of the Arnhem Land Reserve, policed at the border by the Australian state to prohibit entry by Europeans. Some of my research collaborators today were born in the bush between the 1920s and 1950s and spent their early life intentionally at a distance from colonial authority and other Balandas at the frontier.

Given the focus here on access to food as an idiomatic expression of the good life, it is of interest that Kuninjku are related to people to the west who had migrated to the mission at Oenpelli, and who had participated in a research experiment of hunter-gatherer living conducted by the 1948 Arnhem Land expedition (see Thomas \& Neale, 2011). Without rehearsing too much detail, information collected by McCarthy and McArthur (1960) at Fish Creek (or Kunnanj) in October 1948 provided the ethnographic evidence for Sahlins's (1972) theorisation of the 'original affluent society' in his Stone Age Economics. This theorisation continues to have some influence today (Gammage, 2011). Sahlins (1972) also 
theorised that people like the Kuninjku engaged in a particular form of domestic moral economy-'a domestic mode of production' that was largely self-sufficient, sustainable and based on the moral imperative to share in a generalised manner with kin and co-residents.

I have taken issue with elements of Sahlins's depiction of 'original affluence', mainly because my fieldwork experience and primary data collection suggest that while there was seasonal surplus, there was also a degree of seasonal precarity involved in living off the land. Even today, with access to bought food and modern technology, making a living out in the bush during the wet seasons is difficult because of seasonal flooding and inaccessibility of wildlife (Altman, 1987, 2011). Moreover, some forms of bush food collection were, and continue to be, arduous in terms of work effort. However, there is no doubt that as hunter-gatherers, Kuninjku people had a sustainable mode of production. As Hamish, one of my Kuninjku interlocutors, put it: 'The old people had the true power to be self-sufficient. They worked hard producing food to survive, yams, all kinds of food they carried and shared ... with others'.

While Kuninjku had occasional contact with the colonial state, explorers, pastoralists and missionaries in the period prior to World War II, patrol reports document populations still living in the bush as hunter-gatherers from the 1930s to the 1960s (Altman, 2016). All this changed in 1957 with the establishment of a government settlement at Maningrida, followed by the blazing of a bush vehicular track from Oenpelli mission to Maningrida through Kuninjku country in 1963. After 1963, most Kuninjku moved to live in Maningrida although many continued seasonal visitations back to their country for hunting and ceremonies.

The Kuninjku hunting economy more or less disappeared when they lived in Maningrida. State colonial domination sought to centralise and sedentarise these mobile hunter-gatherers to prepare and equip them for integration as citizens into the settler society. This initial social engineering project of improvement was grounded in an explicit policy of assimilation, articulated in 1961:

All aborigines and part-aborigines are expected eventually to attain the same manner of living as other Australians and to live as members of a single Australian community enjoying the same rights and privileges, accepting the same responsibilities, observing the same customs and influenced by the same beliefs, hopes and loyalties as other Australians. (Commonwealth of Australia, 1961) 
Economic thinking was deeply influenced by the post-war modernisation paradigm of the time. For many reasons, that grand project of socioeconomic convergence between Indigenous and other Australians failed at Maningrida, as it failed more broadly, especially in remote Australia.

Life at Maningrida represented a radical change from bush living. For a start, Kuninjku were living on other people's country, that of the Dekurridji. They were also living with many other Aboriginal people from the region, as well as Europeans, in a sedentary small township setting. Most importantly, even though Kuninjku, like other Aboriginal people in Australia, were granted voting rights in 1962, at Maningrida they were categorised as wards of the state and subject to the supreme colonial authority of a superintendent sanctioned by Australian law. A radical shift in livelihoods saw people becoming waged labourers on below-award training allowances, or else engaged in one form or another of training for late modernity, including 'domestic duties'. Kuninjku, like others, had access to very rudimentary housing, primary education and basic health services in Maningrida; for a time, they ate in the settlement's communal dining hall as it was deemed the best way to deliver Western food.

Kuninjku adapted very badly to settlement life and the state project of assimilation mainly because they remained strongly committed to their own values regime and notions of autonomy and authority. Consequently, their lot at the settlement, which was notionally established for their betterment and to prepare them for integration into modernity, was precarious. State officials were quick to identify what was then termed 'the Gunwinggu problem', which simply reflected Kuninjku unwillingness to respond to the official solution: imagined assimilation. I say 'imagined' because, as history has subsequently demonstrated, settlements like Maningrida lacked the economic base to engage viably with market capitalism. Part of the solution envisioned by the authorities was for Kuninjku minors to attend school and for their parents to actively engage in make-work or commercially fraught projects heavily subsidised by the state. For many reasons, including bullying by other Aboriginal kids and unimaginative curricula and teaching methods, Kuninjku kids avoided school more than others, while their parents engaged in poorly paid employment reluctantly and sporadically (Altman, 2016).

Maningrida failed as a project of assimilation for two main reasons. First, counter to capitalist logic, the settlement was established as a coastal trading post and then, later, as an entrepôt without any assessment of 
the commodities that might flow from the hinterland. As it turned out, there were very few of any commercial value. Second, and again counter to capitalist logic, a series of state-subsidised projects were established, including forestry, cattle and buffalo raising, dairy, market gardens, orchards, flower propagation, fishing and fish processing, a piggery and chicken raising, without any realistic appraisal of commercial viability or comparative advantage. All failed. Interestingly, the production and marketing of Aboriginal art, which was not supported back then as a state enterprise, has subsequently proven to be the only sustainable commodity export from the region.

Unsurprisingly, as a group regarded by other Aboriginal people at Maningrida as myall (or wild and primitive), living marginalised and impoverished in the township did not suit Kuninjku. They experienced 'structural violence' (Farmer, 2005) and economic deprivation. As John put it: 'Sometimes we Kuninjku kids were hungry and sick, so we didn't like being here [in Maningrida]'. Many yearned to return to live on their ancestral lands. By the late 1960s, they had taken steps to achieve this aim by purchasing two second-hand cheap vehicles; and there was a growing administrative sympathy on the part of some enlightened local non-Indigenous officials for this aspiration given the evident failure of Kuninjku to adapt to urbanised and sedentarised life.

\section{Decentralisation and Postcolonial Economic Hybridity}

Kuninjku were able to reconstitute a significantly transformed huntergatherer economy in the early 1970s after decentralisation back to their land. This transformation was underpinned by access to welfare and to domestic and global art markets for which Kuninjku art was adapted and commoditised for sale. Out of the failure of the assimilation experiment and a form of precarity living in Maningrida came a period of postcolonial possibility supported by a policy explicitly termed self-determinationthat is, 'Aboriginal communities deciding the pace and nature of their future development as significant components within a diverse Australia' (Australian Human Rights Commission, 2008). 
A new set of government programs was established that supported plural forms of livelihood. Kuninjku people were able to engage productively with these new institutional arrangements and establish what I have termed a hybrid or plural form of livelihood that matched their priorities to remain interconnected to their immediate social community, connected to their ancestral lands and engaged ceremonially with that land in accordance with tradition. All this required a highly flexible mode of living and of making a living-a hybrid economy, which was created and maintained with the crucial assistance of a regional resource agency, the Bawinanga Aboriginal Corporation (BAC).

Two transformative policy shifts facilitated the Kuninjku reconnection to their community lands in the early 1970 s. First, belated recognition of Kuninjku as Australian citizens saw them empowered to find their own solution. Their emerging rights included access to welfare paid to individuals, initially as family allowances and pensions. Deploying their enduring kin-based relations of production allowed the pooling of funds to underwrite their livelihoods as hunters, fishers and harvesters with store-purchased, everyday commodities and important Western equipment, such as vehicles and guns. Second, the progressive Whitlam Government committed to land rights law that legally recognised land ownership by Aboriginal people living on gazetted reserves like Arnhem Land. Recognising an associated escalation in movement back onto country, the government supported the establishment and funding of specially incorporated outstation resource agencies. It also incrementally introduced full entitlement to welfare to 'unemployed' outstation residents, which, because people were rarely work- or income-tested, meant payments effectively operated as a basic income scheme. Added to this was a rapid expansion, from the late 1980s, of funded participation in the community-controlled Community Development Employment Projects (CDEP) scheme. This was a crucially important institution because it allowed earning of extra cash without income testing and accommodated highly flexible living arrangements.

The 30-year period from about 1975-2005 saw a remarkable transformation in the Kuninjku economy and ways of living. Engaging with the new institutions born of an increased tolerance of difference, Kuninjku crafted an unusual hybrid form of economy based on a relatively high harvesting of wildlife for sustenance, successful engagement with market capitalism through the production and sale of art, and creative use of state income support. This form of economy was based on a virtuous 
cycle: unconditional income support at outstations underwrote hunting activity, arts production generated discretionary income that could be invested in vehicles that enhanced access to game on country, which, in turn, generated considerable bush tucker that offset the need for storepurchased foods and also provided greater access to the natural products needed for arts production.

This economic system had many elements that suited Kuninjku. It was flexible and so could accommodate their extraordinarily high levels of residential mobility, often associated with intensified ceremonial participation and sociality, and it was anarchic, so eliminated relations of domination in the workplace, which are anathema to Kuninjku values. It was an economy predicated on an arguably serendipitous understanding of what Westerners might define as the Ricardian (after David Ricardo) principle of comparative advantage and a growing division of labour by specialisation (rather than just by gender). The customary skills that Kuninjku had managed to retain during their time in Maningrida in the 1960s could now be deployed to self-provision and to produce commodities in the form of fine art for export. Over time, new specialisations emerged, for example, in the production of textile art, land and resource management and and the performance of ritual services in the Aboriginal domain.

By 2005, the Kuninjku, who had been the most marginalised and impoverished 'community' in the 1960s, were the most successful regionally; Kuninjku artists were travelling internationally for exhibitions and fêted as Australian cultural ambassadors. They produced the majority by value of exports from the region in the form of art. Their enhanced regional status saw them increasingly take up residence in Maningrida, where their ownership of high-status four-wheel drive vehicles not only made their economic success highly visible, but also allowed a high degree of movement between Maningrida and outstations in the hinterland. Some Kuninjku lived and sought to make a living and get food mainly in Maningrida; others lived mainly at outstations; many lived across the two.

From the early 1970s, Kuninjku had found their own solution to what the authorities had dubbed 'the Gunwinggu problem' and to what Kuninjku had found an utterly unacceptable way of living, regimented by white authority (Altman, 2016). However, this form of apparent economic justice was not the product of Kuninjku agency or serendipity alone. It was also highly dependent on funded programs that supported Kuninjku 
desires to live differently. Of crucial importance was BAC, established in 1979 as an outstation resource agency, and Maningrida Arts and Culture (MAC), established in 1973 to assist with the marketing of art, which became a business unit within the far larger BAC.

I cannot describe here in any detail the evolution and life cycles of these two organisations that played an instrumental role in the emergence of Kuninjku success. I just note that BAC was incorporated as a special institution of the self-determination era to provide services and support to its members, including those Kuninjku who were mainly outstation residents in its early years. BAC grew rapidly from humble beginnings to become a significant regional organisation. It transformed into a major employer from 1989, when it became host of the nation's largest CDEP scheme of some 600 participants. It used access to this multimillion dollar program to develop into a profitable regional development agency. Politically, BAC developed a reputation as a progressive organisation that advocated for land rights, appropriate forms of economic development, outstations support and regional self-determination for its members and their families. From the Kuninjku perspective, and very concretely, BAC assisted with income support and services out bush, the latter including delivery of Western food supplies; access to guns and gun licences; access to vehicles (via assistance to saved money in 'truck' accounts) and assistance with their purchase; and assistance with vehicle registration, repair and servicing.

MAC, as a business arm of BAC, became very effective in marketing art, and especially Kuninjku art. By 2004, there were about 100 Kuninjku artists (out of an estimated population of 300) selling art via MAC and responsible for nearly 60 per cent of turnover; by 2007-08, as MAC's turnover peaked, close to AUD1 million per annum was being paid to Kuninjku artists.

In terms of an overarching framework, one can analyse the postcolonial transformation of the Kuninjku way of life by deploying Fraser's (2009) three dimensions of social justice: recognition, redistribution and representation. BAC advocated for recognition of Kuninjku difference through political representation; it administered CDEP scheme income support effectively and provided other important services, such as managed savings accounts for the purchase of vehicles as member-tailored forms of redistribution. 
The Aboriginal and Torres Strait Islander Commission (ATSIC), a democratically elected institution established by the Australian Government in 1990 (and abolished in 2004), advocated strongly at the national political level, and at international forums, for recognition of the right of Indigenous people like the Kuninjku to live on their traditional lands and to live differently (ATSIC, 1995). Coincidentally, ATSIC also administered and championed the CDEP scheme, its largest program; ran the Community Housing and Infrastructure program, which provided limited financial support to outstation resource agencies for housing and infrastructure; and, under its cultural policy, assisted art centres like MAC.

For a period of over 30 years, these institutional arrangements delivered helpful support that allowed Kuninjku to actively pursue meaningful livelihood opportunities. However, this tolerance of difference came at a cost, as they missed out on some citizenship entitlements when residing at outstations or Maningrida; housing was overcrowded and rudimentary; medical services were limited; and educational opportunities were extremely narrow, delivered only in English and often totally absent at outstations. Yet, by the early twenty-first century, Kuninjku had found their own form of hybrid livelihood, increasingly living between town and country and benefiting from the political representation for this mode of living provided by BAC. Nevertheless, Kuninjku were highly dependent on both the state and their regional organisation, which left them vulnerable to dramatic policy shifts.

\section{Neo-Colonial Intervention for Neoliberal Assimilation}

Over the past decade, the Kuninjku community has become entangled in national welfare and Indigenous policy-reform processes and a global economic downturn that clearly demonstrate this vulnerability and underline their inability to influence state power and policy unilateralism. This powerlessness has seen the rapid erosion of the transformative gains of the previous 30 years. Today, Kuninjku are caught up in a broader reconceptualisation of the 'Aboriginal problem' that has gained considerable following among the political, bureaucratic and corporate elites, and increasingly in public perception as well. 
A second wave of colonisation and new forms of state experimentation has emerged once again in the name of improvement. Underpinning this second wave of domination, which appears unaware of the disasters of the past, has been a generalised view that the nature of the transformation of remote-living Aboriginal people has been a development failure. This failure is blamed on excess dependence on welfare, permissiveness allowed from the advent of the self-determination era and subsequent associated social and community dysfunction (Pearson, 2000; Sutton, 2009).

This dominant view has justified a paternalistic and discriminatory intervention in the Northern Territory since 2007 that has quite explicitly sought to alter the norms and values of Indigenous people to accord with Western ones. A policy discourse has emerged that seeks a fundamental shift of Aboriginal world views away from a relational focus on family, community and attachment to land, to those of the imagined neoliberal subject focused on individualism and material accumulation, and on heightened engagement with the free market.

This recolonising project imposes centralisation in Maningrida, once again, in line with state-enforced engagement with standard forms of Western education, employment and enterprise, irrespective of the absence of conventional labour markets or market opportunity. Despite the developmental rhetoric and neoliberal reasoning of governments in their seeking to 'develop the north' (Australian Government, 2015), this new project to deliver 'advancement' for Aboriginal people through integration is occurring at a time of great global uncertainty about the future of late capitalism in general, and conventional forms of paid work in particular. It is also influenced by a mood of selective austerity, as evident in welfare reform arguments that hold that the (rich) Australian state cannot afford the cost of servicing small, dispersed Aboriginal communities as it must repay high national debt (largely generated by excessive middle-class welfare and tax concessions for the rich).

Consequently, in the present, we see a process of recolonisation with associated radically altered institutional arrangements. The social contract that had emerged to underwrite the Kuninjku hybrid economy has been shattered, and a new Kuninjku precarity has re-emerged, reminiscent of the 1960s. 
I choose 2004 as the starting point for this latest project of improvement inspired by neoliberal values (although I realise that this shift has earlier origins in a longstanding conservative ambivalence towards land rights and notions of Indigenous difference), as it was in 2004 that ATSIC was abolished and a new form of mainstreaming was introduced. ATSIC's suite of programs, including those beneficial to groups like the Kuninjku, were dispersed to mainstream agencies, and with them the political apparatus that had promoted difference and diversity was dismantled.

I will not recount this recent complex history of policy change and associated political disputation here in detail; this has been done elsewhere (e.g. Altman, 2014; Rowse, 2012; Sullivan, 2011). My synoptic analysis instead looks to summarise features of relevance to the Kuninjku, who have been inadvertently caught up in these dramatic policy shifts and the abolition of the institutions that underpinned their livelihood.

In her research on Indigenous people and crime, Anthony (2013) described the ruse of recognition:

The Janus-face of sentencers shows a face of leniency that basks in its humanity and morality in recognising a wronged group and its cultural peculiarities and a face of penalty that glares at difference with condemnation to rationalise its exclusion of a risk group. (p. 27)

Since 2004, this Janus-face has been very evident in what I term 'the ruse of tolerance' as policy has shifted to eliminate the right to be different, with disastrous consequences for groups like the Kuninjku and their own transformative project.

The new governmental approach has three elements. First, there has been a broad discursive shift away from viewing remote Indigenous communities as disadvantaged to viewing them as dysfunctional. This shift has been most clearly seen in the Northern Territory with the National Emergency Response, known as the 'Intervention', first instigated in June 2007, a project that refers to failed states, laments disorder and seeks to recolonise remote Indigenous communities and spaces to reconnect Indigenous citizens to the mainstream (Dillon \& Westbury, 2007). This project was implemented unilaterally, punitively and paternalistically by the Australian Government, aided and abetted by right-wing think tanks, opportunistic bureaucrats and some influential Indigenous actors. 
Second, in line with trends in other rich Western countries, Australia has embarked on a project of welfare reform that has redefined citizenship not just in terms of rights, but also in terms of 'balancing' responsibilities, including the responsibility of individuals to use welfare in a manner that enhances productive engagement with mainstream education and the labour market (see Bielefeld, 2014, pp. 722-23). Such views have been given moral authority by the influential writings of Indigenous political actors like Noel Pearson $(2000,2009)$. At the same time, there has been a shift in welfare policy influenced by neoliberal thinking, which sees marginalisation as a product of individual failing rather than of politicostructural factors, including discrimination and racism (see Bourgois, 2003; Standing, 2014).

Third, there has been the promotion of a utopian myth that a market capitalist solution is possible in remote Indigenous Australia-all that is needed is the promotion in Arnhem Land of the free market ideas of Friedrich Hayek, Milton Friedman and Hernando de Soto and all economic and social problems will be solved! Wiegratz (2010) referred to this as the promotion of 'fake capitalism'. Alternatively, following Cahill (2014), one might interpret this emerging state project, in close alliance with the capitalist plutocracy, as seeking to embed neoliberalism throughout Indigenous Australia in class, ideological and institutional forms. However, this is not a neoliberalism based on the free market but, rather, one that is ideologically conflicted and dependent on state intervention to first morally restructure Indigenous subjects using behavioural carrots and sticks.

The problem with the 'new' approach is that it is based on blind faith and continues to ignore any inconvenient evidence that it might not work. Nowhere is this clearer than in Arnhem Land, where major resource extraction projects like the Ranger uranium mine and Gove bauxite mine are facing either closure-the Ranger mine in 2020-or major downgrading, as happened at Gove, after 45 years of operation, with the closure of a massive alumina processing plant. Despite the evidence that mining is not sustainable, developmental ideology encapsulating current policy rhetoric to 'develop the north' (Australian Government, 2015) persists. 
From the Kuninjku perspective, this radical shift in policy is bewilderingan imposed, imagined new solution to deep structural challenges that were being slowly and productively addressed in collaboration with BAC. Suddenly, Kuninjku, like other Indigenous peoples in remote Australia, are reclassified as undeserving poor who need to be managed with new technologies of surveillance (especially to manage individual expenditures via electronic debit cards), and their behaviour punished and rewarded as subjects of experiments deploying Western behavioural economics.

When in Maningrida, Kuninjku are vulnerable to charges of child neglect, especially with heightened surveillance by roving social workers; they are liable to lose welfare income or be fined for high levels of school absenteeism; they live in overcrowded housing that appears disorderly; and are disengaged from mainstream forms of paid employment because their preferred alternative life way, developed over the last few decades, has prepared them poorly for the few regimented jobs that might be available. What is most concerning is that with such paternalistic governmentality, the postcolonial possibilities of the previous three decades have been demolished in the name of improvement.

Structurally, this has occurred because local political and economic institutions that were of fundamental importance to the operation of the Kuninjku hybrid economy have either disappeared or been drastically weakened. In the name of creating so-called real jobs, which are neither regionally available nor desired, the CDEP scheme has been abolished and replaced by a work for the dole program that requires Kuninjku to work 25 hours a week for their welfare entitlement, week in, week out, year in, year out. The new institution, first called the Remote Jobs and Communities Program and then renamed the Community Development Programme, has proven more successful in penalising participants for non-compliance-largely a result of its demanding requirements-than in finding employment for the 950 people registered as unemployed in the region.

For Kuninjku, this new scheme, having replaced the income security provided by the CDEP scheme, means less income and comes with the constant risk of being in breach of activity requirements (like attending scheduled meetings, training or some designated activity). There is also the risk that extra earnings will see the application of the social security income taper, as more earned income results simultaneously in less welfare income. While the program is administered by BAC, there are now 
multiple external, rather than just one, community forms of accountability and much time wasting and bureaucratic engagement-meta work that interferes with productive work in the hybrid economy. Moreover, Kuninjku occupations such as hunter, fisher, artist and ceremony specialist are not recognised as legitimate forms of 'employment' or 'activity'.

The story of BAC's declining fortunes is complex, and politically fraught. From 2004, BAC opposed destructive reform of the CDEP scheme. In 2007, it vigorously opposed the Northern Territory Intervention, including a unilateral Australian Government decision to transfer responsibility for outstations to the Northern Territory Government. BAC then underwrote a High Court challenge by key Maningrida traditional owners to the compulsory leasing of their land by the Australian Government for five years. The High Court found against the plaintiffs and BAC had to wear costs (since forgiven) of AUD1 million. Up until 2009 , BAC robustly managed to represent the livelihood interests of its members. However, in 2010, new senior management attempted to comply with the government's developmental agenda without proper business planning, with dire consequences. Two years later, BAC went into special administration, insolvent and AUD10 million in debt. Only in July 2014 did BAC emerge, much diminished, from special administration, with debts of AUD3.5 million, to be repaid over five years, and a 'threatening shelved' liability to government of AUD6.5 million.

Unsurprisingly, since 2010, BAC's capacity to deliver a distinctive mix of social, cultural and commercial enterprises to its members has been largely curtailed and reoriented to the commercial. One wonders whether it will ever be able to deliver again on its diverse aims to promote the interests of its members. Some might argue that this diminished role suits the agenda of recent and current federal governments.

From a Kuninjku perspective, the decline of BAC's fortunes has been disastrous, in part because BAC's capacity to service the outstations and their vehicles has all but disappeared. A rapid change in management personnel at BAC has also seen a loss of corporate capacity to locally understand the intricate workings of the hybrid economy. Since the change in the corporation's senior management, social relations between management and Kuninjku have not settled; indeed, they have become severely strained. 
MAC represents the clearest point of articulation between the regional economy and market capitalism. Its financial viability, of great relevance to Kuninjku incomes, has declined markedly in recent years. After the global financial crisis, sales of Aboriginal art nationally are estimated to have plummeted by 50 per cent (Office of the Registrar of Indigenous Corporations, 2012). Combined with the negligence of the special administrators that saw no application submitted for government cultural support when most needed, artists' incomes have declined markedly; in 2014, the gross earnings of Kuninjku artists were around 20 per cent of what they were five years earlier. In this respect, it is instructive to note the differential treatment in Australia of those vulnerable to global economic shocks; there have been no industry rescue packages for struggling Kuninjku artists, unlike for many other Australians experiencing technological unemployment. Today, MAC is slowly recovering but it will be some time before it can reach its peak turnover, in 2008-09, of over AUD2.6 million.

Let me summarise this livelihood disaster, which can be largely attributed to institutional changes driven by the Australian Government, as well as to risky engagement with market capitalism, using two frameworks. First, in terms of the hybrid economy (Altman, 2010), each of its three interlinked sectors - the market, the state and the customary-has shrunk; people earn less arts income from the market and, with the demise of CDEP scheme income support, Kuninjku receive less in transfer payments from the state. There is also a decline in the contributions to their diet from hunting, fishing and wild food gathering. This is partly because people have less access to vehicles to get onto country and less services support to live on country. There are other factors too, including acute difficulty in gaining access to vehicles and firearms, processes that were once facilitated by BAC. Conversely, with a heightened police presence in Maningrida in the wake of the Northern Territory Intervention, unlicensed guns and unregistered vehicles are being confiscated at unprecedented rates; people are losing their very means of hunting and arts production, and their ability to inhabit their traditional country.

Second, in terms of Fraser's (2009) social justice framework, an earlier 'recognition' or tolerance of difference has been replaced by intolerance, even at times by some BAC staff who lack local cultural understandings or corporate history, and increasingly prioritise the financial performance of the organisation. The prospects for the recognition of difference have declined as national and regional representative organisations (i.e. ATSIC and BAC) have been abolished or fundamentally altered and depoliticised. 
The bottom line is that, in 2017, after a decade of progressively intensified state intervention to improve livelihoods, the Kuninjku are living more precariously than at any time since I started working with them in 1979, and probably since they moved out of Maningrida in the early 1970s. The structural and economic violence (Farmer, 2005; Peck, 2010) experienced at that time- a result of the exercise of colonial authority and stigma from other Aboriginal groups in Maningrida-is now not only being repeated, but also supplemented by forms of 'bureaucratic torture' (Lavie, 2014) unimagined in the past. All this is occurring in the name of improvement based on neoliberal reason and the elusive promise of forms of conventional development that the state and market capitalism, despite all the rhetoric, are incapable of delivering.

\section{Kuninjku Push Back}

Kuninjku responses to these circumstances have been mixed: some Kuninjku have retreated from engagement with capitalism, others are using enhanced ceremonial participation as a symbol of defiance and as a means to maintain a semblance of their regional status, itself based on difference. A handful have found work: two as rangers, a few as screen printers, one in night patrol, one at the school. It is a turbulent time for Kuninjku and the institutions that championed their difference; the Australian state and its agents are determined to recalibrate Kuninjku, their norms and values, and their institutions, away from the support of difference towards the promotion of sameness.

Kuninjku see all this very clearly; they lament the fact that today they are more impoverished than in the past, as I noted at the start, barely having enough welfare to purchase expensive store-sourced food, increasingly stuck in town and unsupported when at outstations in the bush. To some extent, their analysis, which I will report briefly, is similar to mine and rendered in terms of the social sciences binary of structure and agency. However, Kuninjku give more self-critical attention to their role in creating this situation over external structuring forces than I might, although there are some variations in interpretations about causes among my interlocutors.

On structure, Kuninjku see that both government policy and BAC have changed. As Kuninjku have few Western negotiating skills, especially an absence of English literacy beyond the most basic level, they had become 
heavily dependent on BAC to mediate on their behalf with the Australian state. Consequently, the distinction between government and BAC and the effect of changes of government policy on BAC become entangled and, at times, a little confused. For example, Ivan said:

[In 1979] BAC came and all that time it was good with BAC. We worked with $\mathrm{BAC}$, but then the government rules changed and $\mathrm{BAC}$ started to change too. Then the government came and they made BAC do what the government wanted and then they didn't want to work with us anymore. This was after Ian Munro time [after 2009]. BAC used to make roads for us and so on, but the government policies changed. BAC's policies changed and they didn't want to support us anymore. Why the government rules changed ... and why the government came and made Bawinanga do what the government wanted and then they didn't want to work with us anymore. They got tired of us Bininj. They weren't interested in us anymore?

There has been a process of a loss of enthusiasm from BAC. In the beginning the Balanda were enthusiastic about helping people out bush. Then BAC got very big, more Balanda, and their thinking changed and they lost interest in Bininj. Today there are different Balanda and they are not interested in us and delivering the services to us in the bush. They are interested in their own affairs and they have their own ideas. BAC are supposed to follow our instructions and wishes, but they follow their own agenda. They don't take an interest in what we are saying.

John put things more succinctly: 'I have still got the same law, but the government keeps changing their rules'.

Kuninjku people are feeling acutely what Povinelli (2011) has termed 'the economies of abandonment'. They are deeply concerned about the 'new generation' stuck in Maningrida, developing a taste for Western foods from the store. As Hamish said: 'Today people of this generation are not really standing properly on the ground. They don't tread upon the ground with the same confidence'. Likewise, Samuel said:

[BAC] have changed. They are only concerned about Maningrida. I don't know if they will ever do a tucker run again. Some of us are used to eating bush tucker. We are the last generation to eat bush tucker but the children today they are not used to eating bush food. 
Samuel's sister, Kay, put it this way: 'The young people are tired. The Balanda food has spoilt them'. John added: 'If you stay here in Maningrida you don't learn anything about your country and how to gather food from it. You only think about chicken and Balanda food'.

What worries people most is the constant pressure for the new generation to move to Maningrida, transform into Balandas and forego Kuninjku ways. As John said:

The government wants us to stay here in Maningrida. They want us to come and live in houses here. They make the houses here to attract us ... When people are themselves free to be Bininj they are happy, happy! When they come to Maningrida to live they become like Balanda. 'Hey you blackfella, you have got everything you need in Maningrida, come in here and live here.' But we have got our own country, our outstations too. So I am still pulled between the two.

Kuninjku are pushing back against this latest state assault in two interlinked ways: by maintaining a moral code of sharing with family and by escalating their participation in a transforming ceremonial life. These are big topics that I can only address briefly here.

Sharing remains a fundamental feature of life for Kuninjku people. They continue to participate in such practices, mainly with their kin, and they value sharing behaviour highly. As one of my interlocutors, Hamish, put it: 'We must never refuse any request from family. We must give to them every time'. Sharing game and cash unsolicited, and asking for game properly, especially in ceremonial contexts, are forms of behaviour that are regarded as demonstrating the very best of Kuninjku relational norms and values.

However, even here there is concern about transformational changes associated with living in town. John drew out the differences:

Balanda values are different in relation to sharing. The old people who lived out bush ate bush tucker, yams and all kinds of tubers and plant foods ... [he names them] and you can be an Aboriginal person there sharing it freely. But sometimes Bininj change their thinking and move towards Balanda law or Balanda thinking. They become different; some are living out bush and some are living in Maningrida worried about food. You change when you come to live in Maningrida. 
Hamish elaborated:

In the old days it was very hard to deny a request for food. They had to put the food they hunted out in the open. You couldn't hide your resources. Now you can hide food and money and get away with not sharing. We like people to initiate the sharing but if they don't then we go and ask. We feel they should offer. Some people don't offer. Everyone is different. Some people are more generous than others.

It is in this context that ceremony has taken on added value because it is usually performed away from Maningrida and people can still gain some access to transport from BAC to go to outstations for ceremonial purposes, where Bininj values and hunting for bush tucker dominate. Ceremony in turn has changed and diversified. There are still the old rituals, like Kunabibi, used to discipline initiates through seclusion in bush camps over many months. However, there are also new ceremonies like Yiwarrudj, or Christian fellowship, and funerals that increasingly mix Kuninjku song cycles with English gospel; these ceremonies, which are replacing earlier mortuary ones, can last for weeks on end.

All of these ceremonies constitute work for Kuninjku, as articulated in their language. Such work, though, is inseparable from sociality. It includes work at ceremonies performing song and dance, paid with both Western food and bush tucker; organising and managing ceremonies; garnering resources by soliciting anywhere and from anyone, but especially kin, for assistance to sustain people at ceremonies; and at ceremony-linked hunting, as opportunities arise and are intensified, often using vehicles provided for ceremonial transportation. Conversely, ceremony provides an opportunity to escape Maningrida and Balanda surveillance and supervision, provided one can persuade employers or government officials at Centrelink that this is all legitimate 'cultural practice' in accordance with bureaucratic guidelines.

Ceremonies also have a strong integrative function. They link Kuninjku and other regional groups together to celebrate tradition and to mourn the dead and bury them with proper decorum on their country. Moreover, ceremony allows Kuninjku to assert their difference and their identity, and to make strong public statements about their exclusive spatial domains; increasingly, signs are posted on access roads warning that ceremony is in progress and that any trespassing, even by state authorities like the police, will not be tolerated. 
Yiwarrudj, or Christian fellowship, is especially important in bringing the young together with the old, dancing in front of ghetto-blasters for hours on end. These constitute important ceremonies of hope. Fundamentalism is creeping in, too, as Glenn told us: 'Jesus is coming back and will take the Christians up to the sky and the non-believers will be left behind'. Many Kuninjku traditionalists worry about the emerging tensions between new Christian fellowship and their authentic ceremonies. However, beyond praying to Jesus, what hope is there for the future, for the 'good life' that all my interlocutors increasingly see as something in the past?

\section{Reviving Postcolonial Possibilities}

'How can things be made better?' I ask. John and Kay answer:

It won't get better, can't fix it. Might be change is needed. Country is there, the country is good, but the people are the problem. I don't know what is wrong with them. People want to move around, I'm telling you the right way. Sometimes people want to live here [Maningrida] sometimes they want to go back. Maybe things will get better and change or maybe not. I don't think so.

I would like to finish this chapter on a hopeful note but, like my interlocutors John and Kay, I find it difficult at this moment to be optimistic. It is not that long ago that when I visited we had shared a life way that allowed Kuninjku to move productively, with a high degree of fluidity and assuredness, between capitalist and non-capitalist economic forms. Indeed, through their active agency, Kuninjku people had creatively refigured a form of moral economy that, while heavily transformed, was still dominated by relationships of reciprocity within the Kuninjku community (and beyond) and displayed a high degree of egalitarianism and a sharing ethic characteristic of hunter-gatherer societies (Sahlins, 1972). Using dichotomies that are familiar to anthropologists, one might depict the Kuninjku as having creatively combined gift and commodity economies (Gregory, 1982), maintaining forms of gift exchange with family to push back against white domination while engaging with forms of commodity and labour exchange. When able to do this, life was far better for Kuninjku - people were not hungry and they could access the bush foods they value. 
This fluid form of economy was based on a combination of distinct Kuninjku cultural logic alongside limited market capitalist opportunity. However, in recent years it has clashed with a dominant neoliberal logic that is looking to transform Kuninjku norms and values and preferences to those of mainstream Australians. This state project looks to effectively eliminate people like the Kuninjku by deploying subtle forms of what Lavie (2014) has termed bureaucratic torture and what Peck (2010) has referred to as economic violence. The high dependence of Kuninjku people on basic state support to activate the customary and market sectors of the hybrid economy make them extremely vulnerable to the project to impose a new form of moral economy on them. This raises important questions about the morality of a state apparatus that is willing to crush any resistance to this project of improvement with harsh financial penalties. Market capitalism imposes a moral logic that undermines any semblance of Kuninjku economic autonomy: when demand for art declines Kuninjku suffer, and when incomes decline there is no commensurate decline in the price of basic commodities. Indeed, it seems that as income decreases, people purchase cheaper foods that are less nutritious and do them physical harm.

This pessimistic assessment is not made lightly; it is based on observation of the extraordinary bureaucratic hurdles that Kuninjku need to negotiate on an almost daily basis to bridge cultural and linguistic divides in the absence of effective mediation. I have watched as Kuninjku have gone to the police to try and negotiate the complex processes of getting a gun licence or renewing a driving licence; I have seen vehicles impounded in the remote bush by police for being unregistered and their drivers, responding to requests from kin to go shopping or hunting, fined exorbitant amounts or face imprisonment.

Kuninjku people enjoy land rights and resource rights in remote Arnhem Land but these do not readily translate into the economic right to make a reasonable living on their country. In particular, having failed to reform land rights law to individualise communal lands, the Australian Government is now looking to individualise what is often communal labour through a new work for the dole regime under which Kuninjku people regularly lose access to welfare because they fail to meet some official deadline, often unaware of its existence or of other requirements, which change regularly. 
In an uneven contest of values, the state champions individualism and ways of living calibrated to the standards of the Australian mainstream only, while Kuninjku prioritise relational ideals and ways of being. Kuninjku refuse to acquiesce meekly to the domination of the powerful irrespective of the suffering inflicted in the process. From their perspective, the state is losing legitimacy as it fails to deliver any improvement. Under such circumstances, the economic right of Kuninjku people to a livelihood encompassing a diversity of values is surely worth considering, especially at a time when there is global uncertainty about the future prospects of late capitalism.

The recent policy shift, which I have called neo-colonial, and which constitutes a second wave of colonisation 60 years after the first, is exposing Kuninjku people to welfare reform based on a fictitious notion of free market opportunity in remote Arnhem Land. It is unjust. This can be demonstrated very clearly with the three tests that Standing (2014, pp. 123-24) proposed for assessing whether reforms are socially just. The 'security difference principle' requires a reform to improve the security of the most insecure in society; the 'paternalism test principle' requires that any new controls not be imposed on some groups that are not imposed on others; and the 'dignified work principle' requires all types of productive work to be recognised and respected, not just labour in subordinated make-work activity. Each of these principles is broken in the Kuninjku case: people's income is highly insecure and declining; Kuninjku are subjected to paternalistic controls over welfare and expenditure that other Australians rarely experience; and their forms of work in the customary realm are neither recognised nor respected, even when they contribute to Kuninjku wellbeing.

At the international level, Australia has conjoined the United Nations Declaration on the Rights of Indigenous Peoples, which specifically calls for the recognition and respect of Indigenous rights of self-determination, yet pluralism in Australia is presently at a dead end. How to improve the prospects of the Kuninjku, a very insecure group in Australian society, so that they might be positioned to resist the tyranny of a new social engineering experiment doing them economic harm is a pressing question.

Fraser (2009) suggests that intractable issues of social justice will increasingly need to defer to a higher supranational power or 'intermestic' politics. Ultimately, judicial activism at the international, rather than domestic, level might provide the only means to ensure difference 
recognition for groups like the Kuninjku. How the Kuninjku might garner the political means to appeal to domestic and international publics is, at present, an almost insurmountable challenge. Perhaps the starting point is a politics of embarrassment. How can postcolonial possibilities enjoyed just a decade ago be revived to put an end to the economic violence currently being wrought? How is it that in rich Australia, first peoples like the Kuninjku, with property rights in vast tracts of land and natural resources, struggle to enjoy the fundamental human right to have enough food to eat?

\section{Acknowledgements}

The fieldwork on which this chapter is based was supported by the UK Economic and Social Research Council (ESRC). In writing this chapter, I would like to thank all my Kuninjku friends and interlocutors, especially as recorded here, John Mawurndjul, Kay Linjiwanga, Samuel Namunjdja, Janet Marawarr, Japhed Namunjdja and Ivan Namirrki. I would like to especially acknowledge my close friend Hamish Karrkarrhba who recently passed away prematurely aged just 50 years before the publication of this chapter. I hope that what I describe and analyse here accurately represents their perspectives and circumstances. I would like to thank a number of academic colleagues, especially Chris Gregory (who accompanied me on one field visit), Murray Garde (who accompanied me on another and assisted me enormously in recording interviews in Kuninjku and translating and transcribing them) and Melinda Hinkson, as well as other members of the research team with whom I interacted intensively at workshops in Manchester in 2011, Canberra in 2012, Edinburgh in 2014 and Manchester again in 2015.

\section{References}

Aboriginal and Torres Strait Islander Commission (ATSIC). (1995). Recognition, rights and reform: $A$ report to government on native title social justice measures. Canberra, ACT: ATSIC.

Altman, J. C. (1987). Hunter-gatherers today: An Aboriginal economy in north Australia. Canberra, ACT: Australian Institute of Aboriginal Studies. 
Altman, J. C. (2010). What future for remote Indigenous Australia: Economic hybridity and the neoliberal turn. In J. C. Altman and M. Hinkson (Eds), Culture crisis: Anthropology and politics in Aboriginal Australia (pp. 259-80). Sydney, NSW: UNSW Press.

Altman, J. C. (2011). From Kunnanj, Fish Creek to Mumeka, Mann River: Hunter-gatherer tradition and transformation in Western Arnhem Land, 1948-2009. In M. Thomas \& M. Neale (Eds), Exploring the legacy of the 1948 Arnhem Land expedition (pp. 113-34). Canberra, ACT: ANU E Press. doi.org/10.26530/oapen_459230

Altman, J. C. (2014). Indigenous policy: Canberra consensus on a neoliberal project of improvement. In C. Miller \& L. Orchard (Eds), Australian public policy: Progressive ideas in the neoliberal ascendancy (pp. 115-32). Bristol, England: Policy Press. doi.org/10.2307/j.ctt 1ggjk39.13

Altman, J. C. (2016). Imagining Mumeka: Bureaucratic and Kuninjku perspectives. In N. Peterson and F. Myers (Eds), Experiments in self-determination: Histories of the outstation movement in Australia (pp. 279-300). Canberra, ACT: ANU Press. doi.org/10.22459/esd. 01.2016 .14

Anthony, T. (2013). Indigenous people, crime and punishment. Milton Park, Abingdon: Routledge. doi.org/10.4324/9780203640296

Australian Government. (2015). Our north, our future: White paper on developing northern Australia. Canberra: Commonwealth of Australia.

Australian Human Rights Commission. (2008). Face the facts: Questions and answers about Aboriginal and Torres Strait Islander Peoples. Retrieved from www.humanrights.gov.au/publications/2008-facefacts-chapter-1

Bielefeld, S. (2014). Compulsory income management and Indigenous peoples-exploring counter narratives amongst colonial constructions of 'vulnerability'. Sydney Law Review, 36, 695-726. doi.org/10.1080/ 10383441.2014.979421

Bourgois, P. (2003). In search of respect: Selling crack in El Barrio (2nd ed.). New York, NY: Cambridge University Press. doi.org/ $10.1017 /$ cbo9780511808562 
Cahill, D. (2014). The end of laissez-faire? On the durability of embedded neoliberalism. Cheltenham, England: Edward Elgar. doi.org/10.4337/ 9781781000281

Commonwealth of Australia. (1961, 20 April). Parliamentary Debates, House of Representatives (p. 1051). Canberra, ACT: Australian Government Publishing Service.

Council of Australian Governments. (2011). National Indigenous reform agreement (closing the gap). Canberra, ACT: Council of Australian Governments.

Dillon, M. \& Westbury, N. (2007). Beyond humbug: Transforming government engagement with Indigenous Australia. West Lakes, SA: Seaview Press.

Evans, N. (2003). Bininj gun-wok: A pan-dialectical grammar of Mayali, Kuninjku and Kune (2 vols.). Canberra, ACT: Pacific Linguistics.

Farmer, P. (2005). Pathologies of power: Health, human rights and the new war on the poor. Berkley, CA: University of California Press.

Fraser, N. (2009). Scales of justice: Reimagining political space in a globalizing world. New York, NY: Columbia University Press.

Gammage, B. (2011). The biggest estate on Earth: How Aborigines made Australia. Sydney, NSW: Allen \& Unwin.

Garde, M. (2013). Culture, interaction and person reference in an Australian language. Amsterdam, Netherlands: John Benjamin. doi.org/10.1075/ clu. 11

Gregory, C. A. (1982). Gifts and commodities. London, England: Academic Press.

Lavie, S. (2014). Wrapped in the flag of Israel: Mizrahi single mothers and bureaucratic torture. New York, NY: Berghahn.

Li, T. M. (2015). Can there be food sovereignty here? Journal of Peasant Studies, 42(1), 205-11. doi.org/10.1080/03066150.2014.938058 
McCarthy, F. D. \& McArthur, M. (1960). The food quest and the time factor in Aboriginal economic life. In C. P. Mountford (Ed.), Records of the American-Australian scientific expedition to Arnhem Land. Vol. 2: Anthropology and Nutrition (pp. 145-94). Melbourne, VIC: Melbourne University Press.

Office of the Registrar of Indigenous Corporations. (2012). At the heart of art: A snapshot of Aboriginal and Torres Strait Islander corporations in the visual arts sector. Canberra, ACT: ORIC.

Pearson, N. (2000). Our right to take responsibility. Cairns, QLD: Noel Pearson and Associates.

Pearson, N. (2009). Up from the mission: Selected writings. Melbourne, VIC: Black Inc.

Peck, J. (2010). Constructions of neoliberal reason. Oxford, England: Oxford University Press. doi.org/10.1093/acprof:oso/ 9780199580576.001.0001

Povinelli, E. (2011). Economies of abandonment: Social belonging and endurance in late liberalism. Durham, NC: Duke University Press.

Rowse, T. (2012). Rethinking social justice: From 'peoples' to 'populations'. Canberra, ACT: Aboriginal Studies Press.

Sahlins, M. (1972). Stone age economics. Chicago, IL: Aldine and Atherton.

Schapper, H. (1970). Aboriginal advancement to integration: Conditions and plans for Western Australia. Canberra, ACT: Australian National University Press.

Standing, G. (2014). A precariat charter: From denizens to citizens. London, England: Bloomsbury Academic.

Sullivan. P. (2011). Belonging together: Dealing with the politics of disenchantment in Australian Indigenous policy. Canberra, ACT: Aboriginal Studies Press.

Sutton, P. (2009). The politics of suffering Indigenous Australia and the end of the liberal consensus. Melbourne, VIC: Melbourne University Press. 
Thomas, M. \& Neale, M. (Eds). (2011). Exploring the legacy of the 1948 Arnhem Land expedition. Canberra, ACT: ANU E Press. Retrieved from press.anu.edu.au/publications/exploring-legacy-1948-arnhemland-expedition

Wiegratz, J. (2010). Fake capitalism? The dynamics of neoliberal moral restructuring and pseudo-development: The case of Uganda. Review of African Political Economy, 37(124), 123-37.

Wolfe, P. (1999). Settler colonialism and the transformation of anthropology: The politics and poetics of an tthnographic event. London, England: Cassell.

Wolfe, P. (2015). Traces of history: Elementary structures of race. London, England: Verso. 
This text is taken from The Quest for the Good Life in Precarious Times: Informal, Ethnographic Perspectives on the Domestic Moral Economy, edited by Chris Gregory and Jon Altman, published 2018 by ANU Press, The Australian National University, Canberra, Australia.

doi.org/10.22459/QGLPT.03.2018.08 